\title{
Вплив модифікованої плікації шлунка та рукавної резекції шлунка у щурів із глутамат-індукованим ожирінням та стрептозотоцин- індукованим діабетом на динаміку зниження маси тіла та вуглеводний обмін
}

\begin{abstract}
Мета роботи: порівняти вплив модифікованої плікації шлунка та рукавної резекції шлунка у щурів із глутамат-індукованим ожирінням та стрептозотоцин-індукованим діабетом на динаміку зниження маси тіла та вуглеводний обмін.

Матеріали і методи. Дослідження проводили на 45 білих безпородних щурах-самках з вихідною масою тіла 150-180 грам. На тваринах було змодельовано глутамат-індуковане ожиріння та стрептозотоцин-індукований діабет 2-го типу. Тварини було розділено на групи по 15 тварин: контрольну та дві експериментальні. В першій експериментальній групі було виконано рукавну резекцію шлунка, другій експериментальній групі було виконано плікацію шлунка по великій кривині з формуванням 3-ох складок і першому ряді швів та другим рядом непереривних швів. Після чого визначали масу тварин та глюкоза натще на 14-ту, 28-му, 42-гу та 60-ту доби.

Результати досліджень та їх обговорення. Рівень глюкози натще в контрольній групі на 60-ту післяопераційну добу становив $(18,405 \pm 1,2)$ ммоль/л, в першій групі, де було виконано рукавну резекція шлунка, він склав $(9,539 \pm 1,14)$ ммоль/л, в другій групі, де виконано модифіковану плікацію шлунка, він склав $(10,39 \pm 1,49)$ ммоль/л. Визначення глюкози в сироватці крові на 60-ту - післяопераційну добу встановило високо достовірне зниження показників глюкози сироватки крові між контрольною та першою експериментальною групою, де було виконано рукавну резекцію $(\mathrm{p}<0,01)$ та високо достовірне зниження глюкози сироватки крові між контрольною групою та другою експериментальною групою, де було виконано модифіковану методику плікації шлунка $\left(\mathrm{p}^{<0.01)}\right.$. Проте статистично значимої різниці між першою та другою експериментальними групами не виявлено ( $>>0.05)$.

Маса тіла тварин контрольної групи на 60-ту добу становила $(335 \pm 17,32)$ г, в першої експериментальної групи на 60 -ту добу склала $(260 \pm 12,96)$ г та в другій експериментальній групі - $(258,33 \pm 11,44)$ г. Визначення маси тіла щурів встановило статистично достовірне зниження маси тіла на 60-ту післяопераційну добу в щурів, яким було виконано рукавну резекцію шлунка, порівняно з контрольною групою (p<0,01) та статистично достовірне зниження маси тіла в щурів на 60 -ту післяопераційну добу після модифікованої плікації шлунка порівняно з контрольною групою (р<0,01). Проте статистично значущої різниці між масою тіла у щурів першої та другої експериментальних груп на 60-ту післяопераційну добу не виявлено (р>0.05).
\end{abstract}

Ключові слова: плікація шлунка; рукавна резекція шлунка; морбідне ожиріння; цукровий діабет.

Постановка проблеми і аналіз останніх досліджень та публікацій. Відомо, що ожиріння досягло розмірів глобальної епідемії. Згідно з даними ВООЗ, станом на серпень 2014 р. кількість людей з ожирінням подвоїлась порівняно з 1980 р. У 2008 р. більше 1,4 млрд дорослого населення мали надмірну масу тіла, 3 них у 200 млн чоловіків та близько 300 млн. жінок діагностовано ожиріння. 42 млн дітей віком до 5 років мали надмірну масу тіла або ожиріння в 2013 р. Близько 3,4 млн дорослого населення помирає щорічно в результаті виявлення в них надмірної маси чи ожиріння. У 44 \% пацієнтів причиною діабету є надмірна маса та ожиріння $[1,2,3]$. Зокрема, загроза діабету існує в $64 \%$ чоловіків та $77 \%$ жінок, що страждають від ожиріння [4]. Проблема є актуальною і для України. Надмірну масу виявляють у 29,7 \% жінок і 14,8 \% чоловіків, ожиріння, відповідно, у 20,4 та $11 \%$. Актуальність проблеми пов'язана, насамперед, з загрозою інвалідизації пацієнтів та зменшенням тривалості життя, що спричинено виник- ненням супутніх захворювань: серцево-судинних (ішемічного інсульту, інфаркту міокарда, артеріальної гіпертензії, варикозної хвороби), опорнорухового апарату, жовчнокам'яної хвороби, цукрового діабету, дихальної недостатності. ВООЗ назвала ожиріння епідемією XXI століття [5].

Зміна способу життя, що включає низькокалорійну дієту з обмеженим споживанням жирів, фізкультура $є$ основним у лікуванні пацієнтів із морбідним ожирінням [6]. Проте вплив дієт і вправ дає результат у віддаленому періоді лише у 10 \% випадків консервативного лікування. Показанням до хірургічного лікування ожиріння $є$ МО (IMT понад $40 \mathrm{\kappa г} / \mathrm{M}^{2}$ ), що існує протягом 5 років. За наявності тяжких супутніх захворювань, зокрема цукрового діабету 2 типу, неконтрольованої артеріальної гіпертензії, серцевої недостатності операційне втручання пропонують проводити за IMT 35 кг/м². За IMT менше 35 кг $/ \mathrm{M}^{2}$ показано консервативну терапію [5, 7, 8, 9]. Проте в США протягом останніх 5 років розглядається питання про розширення 
показань для хірургічного лікування пацієнтів з I класом ожиріння (IMT 30-35 кг/м²) [10].

Згідно з підсумковими рекомендаціями та керівництвом 2-го саміту діабетичної хірургії операційному лікуванню цукрового діабету 2-го типу 3 морбідним ожирінням підлягають пацієнти з IMT $\geq 40 \mathrm{Kг} / \mathrm{M}^{2}$, для азіатів з IMT $\geq 37,5$ кг/ $\mathrm{M}^{2}$. Пацієнтам $з$ IMT 35-39,9 кг/м², для азіатів - IMT 32,537,4, у яких на фоні оптимізації способу життя та прийому ліків, окрім інсуліну, не досягнуто глікемічного контролю (слабкий глікемічний контроль) та пацієнтам з IMT - 30-34,9 кг/м² для азіатів - 27,5-32,5 кг/м², у яких на фоні оптимізації способу життя, прийому пероральних ліків та інсуліну, не досягнуто глікемічного контролю [11].

Відомо не менше 64 способів баріатричних операцій, які можна розділити на 3 групи: мальабсорбтивні втручання, операції, що зменшують об’єм шлунка (гастрорестриктивні) та комбіновані операційні втручання (гібридні) [1].

Основними вимогами до операцій при метаболічному синдромі є: значне і стабільне зниження маси тіла, усунення інсулінорезистентності, гіперглікемії, порушень ліпідного обміну; при морбідному ожирінні - повинна бути технічно простою у виконанні, з мінімальною частотою ускладнень; можливість післяопераційного рентгенологічного контролю; операція повинна бути зворотною [12].

Також варто зазначити, що попри переваги повздовжньої плікації шлунка, особливо у пацієнтів з ЏД 2-го типу, ці операційні втручання потребують оптимізації, оскільки в пацієнтів, котрим були виконані дані втручання, була повна або часткова функціональна та/або анатомічна непрохідність. Функціональна непрохідність виникала за рахунок значного набряку слизової оболонки шлунка, анатомічна за рахунок надмірного стискання шлунка, особливо в ділянці кута шлунка [13]. Також горизонтальна плікація шлунка може супроводжуватись виникненням таких ускладнень, як поява псевдодивертикулів стінки шлунка, деплікація шлунка та розширення області дна шлунка.

Недостатньо вивченими є питання вуглеводневого обміну при операціях плікації шлунка у пацієнтів з ЦД 2-го типу. Також більш детального вивчення потребує вивчення підвищеного жирового катаболізму в післяопераційний період. Потребує оптимізації методика виконання плікації шлунка з метою попередження можливих ускладнень. Дослідження в цій сфері допоможуть знайти нові стратегії в лікуванні морбідного ожиріння та цукрового діабету 2 типу.

Мета роботи: порівняти вплив модифікованої плікації шлунка та рукавної резекції шлунка у щу- рів 3 глутамат-індукованим ожирінням та стрептозотоцин-індукованим діабетом на динаміку зниження маси тіла та вуглеводневий обмін.

Матеріали і методи. Дослідження проводили на 45 білих безпородних щурах-самках із вихідною масою тіла 150-180 г, що утримувались у віварію Тернопільського державного медичного університету імені І. Я. Горбачевського (Свідоцтво про атестацію № 053/13, видане 04.03.2013 р.). Усі тварини підлягали карантину у віварію (10-15 діб) перед проведенням дослідження, спостерігались на предмет можливої патології. До проведення досліджень їх годували один раз на добу вранці, енергетична цінність їжі складала 5,6-6,3 ккал/кг маси на добу. Доступ до води був необмежений. Тварини були поділені на групи по 15 тварин: 2 експериментальні та одна контрольна. Утримання тварин та маніпуляції з ними проводили згідно 3 додатком 4 до “Правил проведення робіт з використанням експериментальних тварин”, затверджених MO3 України № 755 від 12 серпня 1997 р. [14] “Про заходи щодо подальшого вдосконалення організації форм роботи з використанням експериментальних тварин” та положення “Загальні етичні принципи експериментів на тваринах”, ухваленим Першим національним конгресом із біоетики $[15,16]$, а також відповідно до вимог Порядку проведення науковими установами дослідів, експериментів на тваринах [17]. Утримання тварин та експерименти проводили відповідно до положень “Європейської конвенції про захист хребетних тварин, які використовуються для експериментів та інших наукових цілей” (Страсбург, 1985), “Загальних етичних принципів експериментів на тваринах”, ухвалених Першим національним конгресом з біоетики (Київ, 2001).

На всіх тваринах протягом 25 діб було змодельовано ожиріння за методом, що включає застосування індуктора харчового потягу - натрію глутамату в співвідношенні 0,6:100,0 кормової суміші, а добовий раціон збільшено на 50 \% [18]. Тварини були розділені на 3 групи. Після збільшення маси тіла тварин у середньому на 66,7 \% у всіх 3-х групах був індукований цукровий діабет 2 типу за методикою А. А. Спасова та співавт. [19]. Цукровий діабет викликали шляхом одноразового введення стрептозотоцину (приготованому на 0,1 моль цитратному буфері, рН=4,5), фірми “Sigma”, внутрішньоочеревинно з розрахунку 65 мг/кг, попередньо за 15 хв тваринам було введено інтраперитонеально нікотинамід в дозі 230 мг/кг.

321 доби тваринам контрольної групи виконано серединну лапаротомію з виведенням шлунка в 
рану та мобілізацією сальника від великої кривизни шлунка. Після чого виконували ушивання черевної стінки: очеревина та апоневроз неперервним швом та шкіра - окремо.

Тваринам першої експериментальної групи з 21 доби після моделювання цукрового діабету 2-го типу виконано рукавну резекцію великої кривизни шлунка з ушиванням лінії резекції дворядним швом: перший ряд швів: окремі шви через всі шари стінки шлунка, другий ряд швів: окремі серосерозні шви. Лінія резекції проходила 3 відступом 3 мм від кута Гіса до точки, що знаходилась за 5 мм від пілоруса шлунка по великій кривизні. В обох рядах швів використовували шовний матеріал поліпропілен 5-0 (PROLENE® 5-0 Polypropylene Suture, Ethicon США). Після чого виконували ушивання черевної стінки: очеревина та апоневроз неперервним швом та шкіра - окремо.

Тваринам другої експериментальної групи з 21 доби було виконано модифіковану плікація шлунка. Методика накладання 2 рядів швів на стінку шлунка зі сторони великої кривизни. Перші ряди накладали неперервними швами з відступом 3 мм від кута Гіса вздовж великої кривизни шлунка до точки, що розташована на 6 мм проксимальніше пілоруса шлунка по великій кривизні, відповідно, на передній та задній стінках шлунка 3 відступом на відстані від лінії мобілізації сальника на великій кривизні шлунка, що складала 30 \% стінки шлунка. При цьому близько 10 \% ширини кожної стінки шлунка занурювалась всередину. Другий ряд швів накладали неперервним швом із формуванням серо-серозних швів, проведених через 4 точки зі сторони великої кривизни та формуванням трох складок стінки шлунка. Точками вколу були відстані симетричні від перших рядів швів та між собою, які були на відстані 10 \% від відповідної стінки шлунка зі сторони від середини великої кривизни. Таким чином формувалась плікація з трьома складками шлунка. Дві складки вгорнуті всередину були більшими та розташовувались ближче до передньої та задньої стінок шлунка. Середня складка була менших розмірів. Таким чином формувався канал вздовж малої кривизни шлунка та посилювався каркас стінок шлунка, що попереджувало розвиток функціональної та анатомічної непрохідності шлунка в ділянці кута шлунка з одночасним укріпленням каркасу шлунка, без розкриття просвіту травного тракту. Для накладання швів використовували шовний матеріал поліпропілен 5-0 (PROLENE® 5-0 Polypropylene Suture, Ethicon США). Накладання неперервних швів попереджує формування псевдодивертикулів стінки шлунка.
У всіх групах тваринам перед операційним втручанням одноразово внутрішньом'язово із профілактичною метою вводили антибіотик "Цефтріаксон” із розрахунку 50 мг/кг та інгібітор протонної помпи протягом 7 днів після втручання з розрахунку один мг/кг.

Хірургічні втручання виконували під тіопенталовим наркозом із розрахунку 30 мг/кг з дотриманням правил асептики та антисептики. В післяопераційному періоді вимірювали масу тіла на 14ту, 28-му, 42-ту та 60-ту доби.

На 60-ту добу щурів декапітували під тіопенталовим наркозом (70 мг/кг) та визначили рівень глюкози в сироватці крові натще (Human $\mathrm{GmbH}$, Hiмеччина) шляхом забору крові з порожнини серця після надсікання верхівки. Для мікроскопічного дослідження проводили забір шлунка, печінки та підшлункової залози у всіх тварин. Матеріал фіксувався у $10 \%$ розчині формаліну та заливався у парафінову блоки. Для патоморфологічного дослідження фарбування препаратів виконували гематоксиліном та еозином. Проводилась порівняльна мікроскопія та зйомка мікропрепаратів на мікроскопі на збільшенні об’єктива 10 та окуляра 10.

Отримані цифрові дані обробляли методом варіаційної статистики. Статистичну обробку цифрових даних здійснювали за допомогою програмного забезпечення "Excel” ("Microsoft”, США) та "STATISTICA" 6. 0 ("Statsoft", США) з використанням параметричних і непараметричних методів оцінки одержаних даних. Для всіх показників розраховували значення середньої арифметичної вибірки (М), іï дисперсії і помилки середньої (m). Достовірність різниці значень між незалежними кількісними величинами визначали при нормальному розподілі за критерієм Стьюдента.

Результати досліджень та їх обговорення. Рівень глюкози натще в контрольній групі на 60-ту післяопераційну добу становив $(18,405 \pm 1,2)$ ммоль/л, в першій експериментальній групі, де було виконано рукавну резекцію шлунка, він склав $(9,539 \pm 1,14)$ ммоль/л, в другій експериментальній групі, де виконано модифіковану плікацію шлунка, він склав $(10,39 \pm 1,49)$ ммоль/л. Визначення глюкози в сироватці на 60-ту добу після операційного втручання встановило високо достовірне зниження показників глюкози сироватки крові між контрольною та першою експериментальною групою, де було виконано рукавну резекцію ( $<0,01)$, та високо достовірне зниження глюкози сироватки крові між контрольною групою та другою експериментальною групою, де було виконано модифіковану методику плікації шлунка 
$(\mathrm{p}<0,01)$. Проте статистично значущої різниці між першою та другою групами не виявлено (p>0,05).

У контрольній групі вихідна маса тіла на момент операційного втручання склала в середньому 336,34 г, на 14-ту добу маса зменшилась у середньому на 28 г і становила в середньому 308,34 г, на 28-му добу маса тіла тварин у середньому збільшилась на 2,67 г за останні 14 діб і склала на 28-му добу в середньому 311 г. За наступні 14 діб маса в середньому збільшилась на 13 г і становила 324 г. Станом на момент виведення тварин з експерименту (60-та доба) маса за останні 18 днів збільшилась в середньому на 11 г і становила в середньому 335 г. У відсотковому співвідношенні до вихідної маси тіла склало відповідно: 14-та доба - 8,3 \%; 28-ма доба - 7,5 \%; 42-га доба $-3,7 \% ; 60-0,4 \%$.

У тварин першої експериментальної групи, де виконано рукавну резекцію шлунка, вихідна маса тіла склала в середньому 351 г. Протягом 14 діб маса тіла в середньому знизилась на 31 г та становила 320 г. На 28-му добу маса тіла тварин становила в середньому 297,33 г та зменшилась за 14 діб на 22,67 г. На 42-гу добу середня маса тіла тварин склала 276,67 г та зменшилась протягом останніх 14 -ти діб у середньому на 20,67 г. На 60-ту добу середня маса тварин у групі складала 260 г та зменшилась у середньому на 16,67 г за 18 діб. У відсотковому співвідношенні до вихідної маси тіла склало відповідно: 14-та доба - 8,8 \%; 28-ма доба - 15,3 \%; 42-га доба - 21,2 \%; 60-та доба - 25,9 \%.

У другій експериментальній групі, де було виконано модифіковану плікацію шлунка по великій кривизні, середня маса тварин на момент виконання операції становила 358 г. За 14 діб маса тіла тварин зменшилась в середньому на 41,67 г та становила в середньому 316,33 г. На 28-му добу маса тіла становила в середньому 289,1 г та зменшилась протягом останніх 14 діб на 27,27 г. На 42-гу добу середня маса тварин в групі становила 270,33 г та зменшилась протягом останніх 14 діб на 18,73 г. На момент виведення тварин з експерименту (60-та доба) середня маса тварин становила 258,33 г та зменшилась в середньому протягом останніх 18 діб на 12 г.

У відсотковому співвідношенні до вихідної маси тіла склало відповідно: 14-та доба - 11,6 \%; 28-ма доба - 19,3 \%; 42-га доба - 24,5 \%; 60 -та доба $-27,8 \%$.

Маса тіла тварин контрольної групи на 60ту добу становила $(335 \pm 17,32)$ г, першої експериментальної групи на 60-ту добу вона склала $(260 \pm 12,96)$ г та в тварин другої експериментальної групи $(258,33 \pm 11,44)$ г. Визначення маси тіла щурів встановило статистично достовірне зниження маси тіла на 60-ту післяопераційну добу в щурів, яким було виконано рукавну резекцію шлунка порівняно $з$ контрольною групою $(\mathrm{p}<0,01)$ та статистично достовірне зниження маси тіла в щурів на 60-ту післяопераційну добу після модифікованої плікації шлунка у порівнянні з контрольною групою $(\mathrm{p}<0,01)$. Проте статистично значущої різниці між масою тіла у щурів першої та другої експериментальних груп на 60-ту післяопераційну добу не виявлено (р>0.05).

Вищеописані результати вказують на ефективність у зниженні рівня глюкози натще у тварин, яким виконано рукавну резекцію шлунка та модифіковану плікацію шлунка порівнняно з контрольною групою тварин. Хоча статистична значущість між рукавною резекцією шлунка та модифікованою плікаціє шлунка при порівнянні показників крові натще немає, в нашому дослідженні все ж у групі тварин, котрим було виконано резекцію шлунка, відмічено виразніше зменшення показників глюкози натще, ніж у групи, де було виконано модифіковану плікацію шлунка.

В усіх групах тварин на 14-ту добу спостерігали значне зниження маси тіла. Проте вже на 28-му добу тварини контрольної групи почали набирати масу, тоді як тварини першої та другої груп продовжували втрачати масу. Маса тварин контрольної групи в середньому на 60-ту добу майже досягнула вихідної. Тварини першої та другої групи показали статистично значущу зміну маси тіла на 60-ту добу порівняно з контрольною групою (рис. 1). Проте не спостерігали статистично значущої зміни маси тіла на 60-ту добу між тваринами першої та другої груп. Водночас у тварин дру-

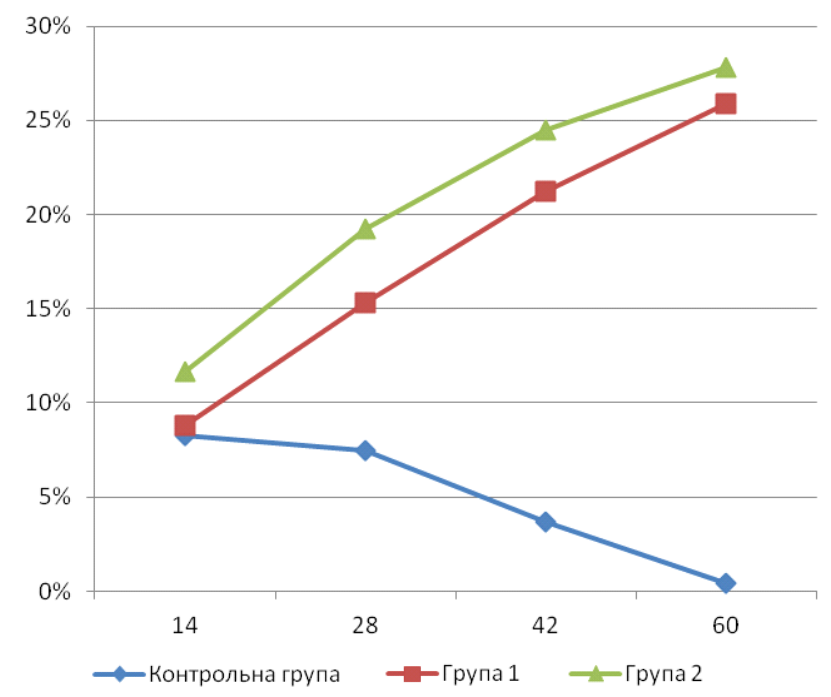

Рис. 1. Динаміка зменшення маси тіла у відсотках від вихідної маси тіла у всіх групах протягом 60 діб. 
гої групи маса тіла зменшилась в середньому більше, ніж у тварин першої групи.

Показники зміни маси тіла та рівень глюкози натще на 60-ту добу дозволяють припустити, що зменшення маси тіла прямо не пов’язане з рівнем глюкози в крові. Ймовірно, більш значне зниження глюкози крові натще у тварин першої експериментальної групи зумовлене відсутністю впливу таких шлункових пептидів, як грелін та інші, що можуть впливати на вуглеводневий обмін та обмін ліпідів (рис. 2).

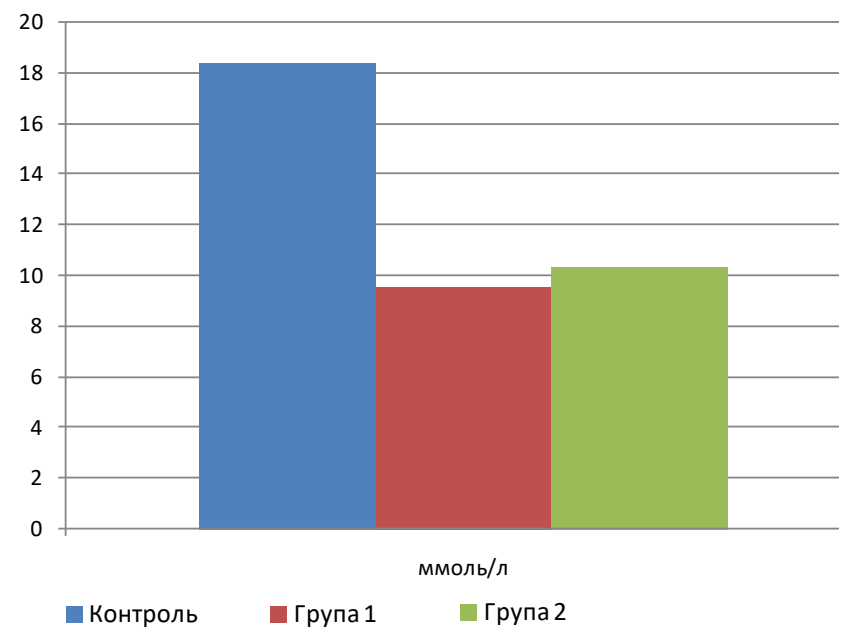

Рис. 2. Рівень глюкози на 60-ту післяопераційну добу в щурів.

Водночас як винятково рестриктивні втручання, дія яких пов’язана зі зменшенням маси тіла та, відповідно, зниженням рівня адипокінів, призводить до зниження рівня глюкози за рахунок зменшення резистентності рецепторів периферичних тканин до інсуліну.

Стосовно мікроморфологічних змін порівняно з групою тварин, яким було виконано рукавну резекцію шлунка, в групі тварин з плікацією спостерігали меншу виразність структурних змін паренхіми печінки та компонентів її строми. Гепатоцити були морфологічно більш повноцінні, а площа деструктивних змін була менша в групі, де виконано плікацію шлунка. Частка інтактних гепатоцитів була більша у групі тварин з плікацією шлунка. Набряк пересинусоїдальних просторів у тварин з резекцію шлунка був виражений частіше і набагато більшою мірою. Також необхідно зазначити, що в групі тварин, котрим виконано рукавну резекцію, значно інтенсивніше виражена лімфоцитарна інфільтрація та деструктивні зміни в острівцях Лангенгарнса. У групі тварин, яким було виконано рукавну резекцію шлунка, значно виразніша некротизація епітеліоцитів та множинні осередки некрозів і десквамації поверхневого епітелію. Десквамація ворсинок утворювала глибокі дефекти епітелію. Одночас- но після рукавної резекції виявлено значні розлади місцевого кровообігу, що спричинили ексудацію плазми в периваскулярні простори з наступним розвитком набряку, який поширювався на підслизовий та м’язовий шари шлунка. В м'язовому шаpi зустрічалися нейтрофільні інфільтрати. Тоді як в групі, де було виконано плікацію, у жодному випадку не відмічено утворення глибоких дефектів епітелію. Проте в деяких тварин відмічено незачний набряк власної пластинки. Також була незначна лімфоцитарна інфільтрація в базальних відділах залоз шлунка. Розлади місцевого кровообігу порівняно 3 групою тварин, яким було виконано рукавну резекцію шлунка, виражені менше і проявлялися ділянками повнокров’я і стазу (рис. 3, 4).

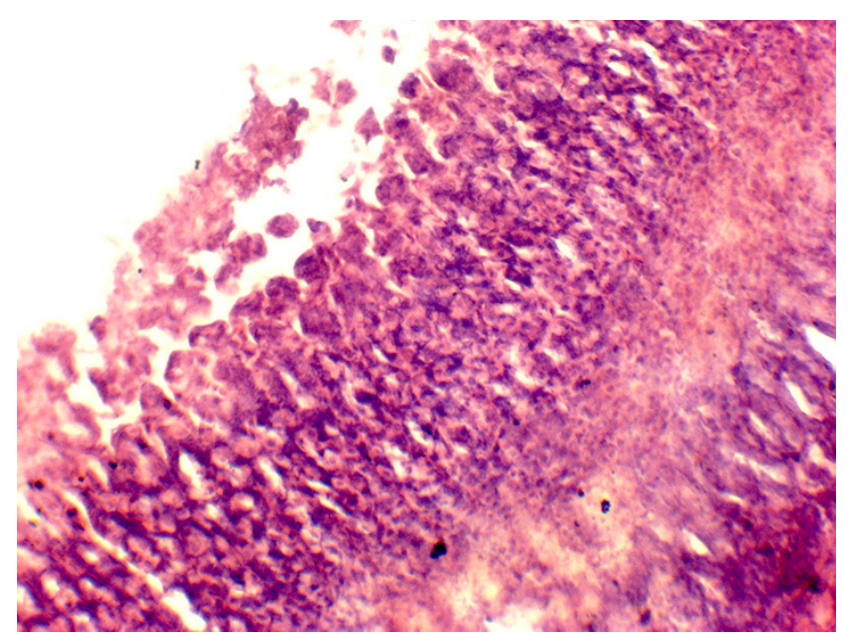

Рис. 3. Гістологічна структура стінки шлунка щура після резекції. Десквамація апікальних відділів ворсинок слизової оболонки із формуванням ерозії. Некротичні зміни у базальних шарах. Забарвлення гематоксиліном і еозином. Ок. 10, об. 10.

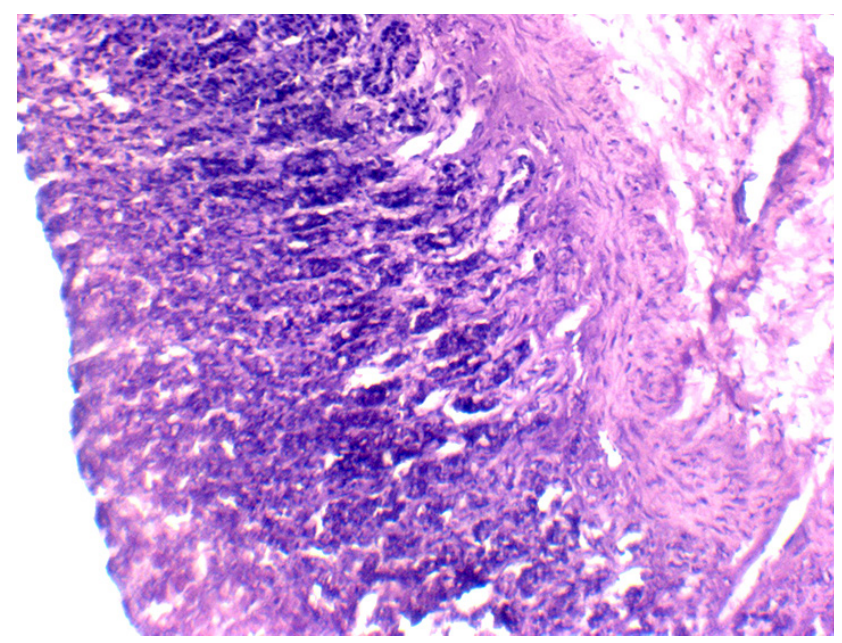

Рис. 4. Гістологічна структура стінки шлунка щура після плікації шлунка. Дистрофія та автолітичні зміни клітин слизової оболонки, набряк підслизової основи із дифузною лімфоцитарною інфільтрацією. Забарвлення гематоксиліном і еозином. Ок. 10, об. 10. 
Висновки. 1. Враховуючи відсутність статистичної значущості в показниках зміни глюкози натще у тварин першої та другої групи на 60-ту післяопераційну добу, можна встановити, що обидва оперативні вручання однаковою мірою знижують рівень глюкози натще у щурів із стрептозотоциніндукованим діабетом та глутамат-індукованим ожирінням.

Беручи до уваги відсутність статистичної значущості в показниках зміни маси тіла у тварин першої та другої групи на 60-ту післяопераційну добу, можна констатувати, що операційні вручання, виконані щурам першої та другої груп, однаковою мірою знижують масу тіла у щурів з стрепто-

\section{СПИСОК ЛІТЕРАТУРИ}

1. В Влив шунтування та бандажування шлунка на рівень показників глюкозо толерантного тесту, інсуліну та С-пептиду у хворих з морбідним ожирінням / О. С. Тивончук, А. С. Лаврик, С. П. Кожара, О. Д. Фурманенко // Ендокринологія. 2008. - Т. 13, № 1. - С. 66-75.

2. Obesity, fat distribution and weight gain as risk factors for clinical diabetes in men / J. M. Chan, E. B. Rimm, G. A. Colditz [et al.] // Diabetes Care. 1994. - Vol. 17. - P. 961-969.

3. Weight gain as a risk factor for clinical diabetes in women / G. A. Colditz, W. C. Willett, A. Rotnitzky, J. E. Manson // Ann. Intern. Med. 1995. - Vol. 121. - P. 4816.

4. Interdisciplinary European guidelines for surgery for severe (morbid) obesity / M. Fried, V. Hainer, A. Basdevant [et al.] // Obes. Surg. 2007. - Vol. 17, (2). - P. 260270.

5. Лаврик А. С. Баріатрична хірургія: Історія до сьогодення / А. С. Лаврик // Клінічна хірургія. - 2012. - № 6. - С. 5-10. 6. Prevalence and trends in obesity among US adults / K. M. Flegal, M. D. Carroll, C. L. Ogden, L. R. Curtin // JAMA. 19992008. - Vol. 303. - P. 235-241.

7. Тивончук О. С. Роль і місце шунтування та бандажування шлунка в сучасній баріатричній хірургії / О. С. Тивончук // Український медичний часопис. - 2007. - № 6. - С. 63-75.

8. Linner J. H. Surgery for morbid obesity / J. H. Linner, R. L. Drew. N. Y.: Springer-Verlag; 1984. - P. 2339.

9. Evidence - based medicine: open and laparoscopic bariatric surgery / P. Gentileshi, S. Kini, M. Catarci, M. Gagner // Surg. Endosc. - 2002. - Vol. 16. - P. 736-744.

10. Review of metabolic surgery for type 2 diabetes in patients with a BMI $<35 \mathrm{~kg} / \mathrm{m} 2$ / H. Shimizu, P. Timratana, P. R. Schauer, T. Rogula // J. Obes. - 2012. - P. 147-256.

11. Francesco Rubino, David M. Nathan, Robert H. Eckel [et al.] // зотоцин-індукованим діабетом та глутамат-індукованим ожирінням.

3. Враховуючи, що операційне втручання є зворотним та водночас не потребує розкриття просвіту шлунка, попереджає ризики розвитку функціональної та анатомічної непрохідності і тим самим знижує ймовірність післяопераційних ускладнень, модифікованій плікації шлунка варто надати перевагу в лікуванні цукрового діабету 2 типу при морбідному ожирінні, особливо у пацієнтів високої групи ризику. Водночас варто зазначити, що подальшого вивчення потребує вплив шлункових пептитів (греліну та ін.) на вуглеводневий обмін та зниження маси тіла при цукровому діабеті 2-го типу.

Diabetes Care Jun. 2016. - Vol. 39 (6). - P. 861877; DOI: 10.2337/ dc16-0236

12. Сравнительные результаты различных методов хирургического лечения тяжелых форм метаболического синдрома / Ю. И. Седлецкий, К. К. Мирчук, А. Е. Неймарк [и др.] // Клінічна хірургія. - 2012. - № 6. - С. 21-26.

13. Милиця К. М. Ускладнення поздовжньої гастроплікації: методи профілактики та способи корекції / К. М. Милиця // Український журнал хірургії. - 2017. - № 1 (32). - С. 68-73. 14. Правила проведення робіт з використанням експериментальних тварин : наказ МОЗ України від 12.08.1997 № 755.

15. Резніков О. Г. Біоетична експертиза доклінічних та інших наукових досліджень, що виконуються на тваринах. [Методичні рекомендації] / О. Г. Резніков, А. І. Соловйов, Л. В. Добреля. - Київ, 2006. - 28 с.

16. Резніков О. Г. Загальні етичні принципи експериментів на тваринах / О. Г. Резніков // Ендокринологія. - 2003. - Т. 8, № 1. - C. 142-145.

17. Про затвердження Порядку проведення науковими установами дослідів, експериментів на тваринах : наказ Міністерства освіти і науки, молоді та спорту України від 01.03.2012, № 249.

18. Пат. UA68839 U Україна, MПК7 G09B 23/28 (2006.01), А61K 31/195 (2006.01). Спосіб моделювання аліментарного ожиріння / Кузів I. Я., Герасимлюк I. Я. (Україна) ; заявник та патентовласник ДВНЗ “Тернопільський державний медичний університет імені І. Я. Горбачевського МОЗ України” ; заявл. 17.10.11 ; опубл. 10.04.12, Бюл. № 7. - 2 с.

19. Экспериментальная модель сахарного диабета типа $2 /$ А. А. Спасов, М. П. Воронкова, Г. Л. Снигур [и др.] // Биомедицина. - 2011. - № 3. - С. 12-18.

Willet, W.C. (1994). Obesity, fat distribution and weight gain as risk factors for clinical diabetes in men. Diabetes Care, 17, 961-969. 3. Colditz, G.A., Willett, W.C., Rotnitzky, A., \& Manson, J.E. (1995). Weight gain as a risk factor for clinical diabetes in women. Ann. Intern. Med., 121, 481-486.

4. Fried, M., Hainer, V., \& Basdevant, A. (2007). Interdisciplinary European guidelines for surgery for severe (morbid) obesity. Obes. Surg., 17 (2), 260-270. 
5. Lavryk, A.S. (2012). Bariatrychna khirurhiia: Istoriia do siohodennia [Barariat surgery: History to the Present]. Klinichna khirurhiia - Clinical Surgery, 6, 5-10 [In Ukrainian].

6. Flegal, K.M., Carroll, M.D., Ogden, C.L., \& Curtin, LR. (1999-2008). Prevalence and trends in obesity among US adults. JAMA, 303, 235-241.

7. Tyvonchuk, O.S. (2007). Rol i mistse shuntuvannia ta bandazhuvannia shlunka v suchasnii bariatrychnii khirurhii [The role and place of gastric bypass and banding of the stomach in modern bariatric surgery]. Ukrainskyi medychnyi chasopys Ukrainian Medical Journal, 6, 63-75 [in Ukrainian].

8. Linner, J.H., \& Drew, R.L. (1984). Surgery for morbid obesity. New-York: Springer-Verlag.

9. Gentileshi, P., Kini, S., Catarci, M., \& Gagner, M. (2002). Evidencebased medicine: open and laparoscopic bariatric surgery. Surg. Endosc., 16, 736-744.

10. Shimizu, H., Timratana, P., Schauer, P.R., \& Rogula, T. (2012). Review of metabolic surgery for type 2 diabetes in patients with a BMI $<35 \mathrm{~kg} / \mathrm{m} 2$. J. Obes., 147-256.

11. Francesco Rubino, David M. Nathan, Robert H. Eckel, Philip R. Schauer, K. George M.M. Alberti, Paul Z. Zimmet, ... David E. Cummings (2016). Diabetes Care, 39 (6), 861-877. DOI: 10.2337/dc16-0236

12. Sedletskiy, Yu.I., Mirchuk, K.K., Neymark, A.Ye., Sedletskaya, E.Yu., \& Anisimova, K.A. (2012). Sravnitelnyye rezultaty razlichnykh metodov khirurgicheskogo lecheniya tyazhelykh form metabolicheskogo sindroma [Comparative results of various methods of surgical treatment of severe forms of metabolic syndrome]. Klinichna khirurhiia - Clinical Surgery, 6, 21-26 [in Russian].

13. Mylytsia, K.M. (2017). Uskladnennia pozdovzhnoi hastroplikatsii: metody profilaktyky ta sposoby korektsii [Complication of longitudinal gastric plication: methods of prevention and methods of correction]. Ukrainskyi zhurnal khirurhii - Ukrainian Journal of Surgery, 1 (32), 68-73 [in Ukrainian].

14. Order of the Ministry of Health of Ukraine dated August 12, 1997 No. 755 "Rules for conducting works using experimental animals". [Pravyla provedennia robit $\mathrm{z}$ vykorystanniam eksperymentalnykh tvaryn]. [in Ukrainian].

15. Reznikov, O.H., Solovyov, A.I., \& Dobrelya, L.V. (2006). Bioetychna ekspertyza doklinichnykh ta inshykh naukovykh doslidzhen, shcho vykonuiutsia na tvarynakh [Metodychni rekomendatsii] [Bioethical examination of preclinical and other scientific researches performed on animals [Methodical recommendations]. Kyiv [in Ukrainian].

16. Reznikov, O.H. (2003). Zahalni etychni pryntsypy eksperymentiv na tvarynakh [General ethical principles of experiments on animals]. Endokrynolohiia - Endokrynology, 8 (1), 142-145 [in Ukrainian].

17. Order of the Ministry of Education and Science, Youth and Sport of Ukraine [Nakaz Ministerstva osvity i nauky, molodi ta sportu Ukrainy] dated 03/01/2012, No. 249. [in Ukrainian].

18. Kuziv, I.Ya., \& Herasymliuk, I.Ya. Pat. UA68839 U Ukraina, MPK7 G09B 23/28 (2006.01), A61K 31/195 (2006.01). Sposib modeliuvannia alimentarnoho ozhyrinnia [Method of modeling of alimentary obesity]. zaiavnyk ta patentovlasnyk DVNZ "Ternopilskyi derzhavnyi medychnyi universytet im. I.Ya. Horbachovskoho MOZ Ukrainy [Applicant and patent holder of the State Medical University "Ternopil State Medical University named after I.Horbachevsky of Ministry of Health of Ukraine]. zayavl. 17.10.11 ; opubl. 10.04.12, Byul. № 7. - 2 s. [in Ukrainian].

19. Spasov, A.A., Voronkova, M.P., \& Snigur, G.L. (2011). Eksperimentalnaya model sakharnogo diabeta tipa 2 [Experimental model of type 2 diabetes mellitus]. Biomeditsina - Biomedicine, 3, 12-18 [in Russian].

\section{K. H. KOZAKOV}

I. Horbachevsky Ternopil State Medical University

\section{INFLUENCE OF MODIFIED GASTRIC PLICATION AND GASTRIC SLEEVE RESECTION IN RATS WITH GLUTAMATE-INDUCED OBESITY AND STREPTOZOTOCIN-INDUCED DIABETES ON THE DYNAMICS OF BODY WEIGHT LOSS AND HYDROCARBON METABOLISM}

\footnotetext{
The aim of the work: to compare the influence of modified gastric plication and gastric resection in rats with glutamate-induced obesity and streptozotocin-induced diabetes on the dynamics of body weight and hydrocarbon metabolism.

Materials and Methods. The study was probed on 45 white, non-breeding female rats with an initial body weight of 150-180 grams. Glutamate-induced obesity and streptotrozine-induced diabetes were modeled on animals. Animals were divided into 3 groups with 15 animals in each control group, and two experimental groups. In the first experimental group we performed sleeve resection of the stomach; in the second one plication of the stomach on a large curvature with the formation of 3 folds in the first row of sutures and the second series of continuous suture. After that, a mass of animals and glucose were determined on the 14th, 28th, 42nd and 60th day. Results and Discussion. The level of glucose in the control group on the 60th postoperative day was $(18.405 \pm 1.2) \mathrm{mmol} / \mathrm{l}$, in the first experimental group, where the sleeve resection of the stomach was made, it was $(9.539 \pm 1.14) \mathrm{mmol} / \mathrm{l}$, in the second group, where the modified gastric plication was made, was $(10.39 \pm 1.49) \mathrm{mmol} / \mathrm{l}$. The determination of glucose in serum on the 60th day after the operation established high statistical significance in decrease of serum glucose between the control and the first experimental group where a sleeve resection was performed $(\mathrm{p}<0.01)$ and a high statistical significance in level of serum glucose reduction was observed between the control group and the second experimental group, where a modified stomach plication technique was performed $(\mathrm{p}<0.01)$. However, no statistically significant difference between the first and second experimental groups was found ( $>0.05)$.

The weight of the body in the control group on the 60th day was (335 \pm 17.32$) \mathrm{g}$, in the first experimental group it was on the 60th day $(260 \pm 12.96) \mathrm{g}$ and in the second experimental group $(258.33 \pm 11.44) \mathrm{g}$. The determination of the body weight of rats found a statistically significant decrease in body weight on the 60th postoperative day in rats, which was performed on the sleeve resection of the stomach in comparison with the control group $(\mathrm{p}<0.01)$ and a statistically significant reduction in body weight in rats on the 60th post-
} 
operative day after modificated gastric plication in comparison with the control group ( $<<0.01)$. However, the statistically significant difference between the weight of the body in rats of the first and second experimental groups on the 60th postoperative day was not revealed $(\mathrm{p}>0.05)$.

Key words: gastric plication (GP); sleeve gastric resection (SGR); morbid obesity; diabetes mellitus.

\section{ВЛИЯНИЕ МОДИФИЦИРОВАННОЙ ПЛИКАЦИИ ЖЕЛУДКА И РУКАВНОЙ РЕЗЕКЦИИ ЖЕЛУДКА У КРЫС С ГЛУТАМАТ-ИНДУЦИРОВАННЫМ ОЖИРЕНИЕМ И СТРЕПТОЗОТОЦИН- ИНДУЦИРОВАННЫМ ДИАБЕТОМ НА ДИНАМИКУ СНИЖЕНИЯ МАССЫ ТЕ.ЛА И УГЛЕВОДНЫЙ ОБМЕН}

Цель работы: сравнить влияние модифицированной пликации желудка и рукавной резекции желудка у крыс с глутаматиндуцированным ожирением и стрептозотоцин-индуцированным диабетом на динамику снижения массы тела и углеводный обмен.

Материалы и методы. Исследование проводили на 45 белых беспородных крысах-самках с исходной массой тела 150-180 г. На животных смоделировано глутамат-индуцированное ожирение и стрептозотоцин-индуцированный диабет 2-го типа. Животные были разделены на 3 группы по 15 животных: контрольную и две экспериментальные, в первой экспериментальной группе было выполнено рукавную резекцию желудка, во второй экспериментальной группе было выполнено пликацию желудка по большой кривизне с формированием 3-х складок в первом ряду швов и с вторым рядом непрерывных швов. После чего измерялась масса животных и глюкоза натощак на 14-е, 28-е, 42-е и 60-е сутки.

Результаты исследований и их обсуждение. Уровень глюкозы натощак в контрольной группе на 60-е послеоперационные сутки составил $(18,405 \pm 1,2)$ ммоль/л, в первой экспериментальной группе, где было выполнено рукавну резекцию желудка, он составил $(9,539 \pm 1,14)$ ммоль/л, во второй группе, где выполнена модифицированная пликация желудка, он составил $(10,39 \pm$ 1,49) ммоль/л. Определение глюкозы в сыворотке крови на шестидесятые послеоперационные сутки установило высоко достоверное снижение показателей глюкозы сыворотки крови между контрольной и первой группой, где было выполнено рукавную резекцию $(\mathrm{p}<0,01)$ и высоко достоверное снижение глюкозы сыворотки крови между контрольной группой и второй экспериментальной группой, где было выполнено модифицированную методику пликации желудка (р <0.01). Однако статистически значимой разницы между первой и второй экспериментальными группами не выявлено (р>0,05).

Масса тела животных контрольной группы на 60-е сутки составляла $(335 \pm 17,32)$ г, в первой экспериментальной группе на 60-е сутки она составила $(260 \pm 12,96)$ г и во второй экспериментальной группе - $(258,33 \pm 11,44)$ г. Определение массы тела крыс установило статистически достоверное снижение массы тела на 60-е послеоперационные сутки у крыс, которым было выполнено рукавную резекцию желудка, по сравнению с контрольной группой $(p<0,01)$ и статистически достоверное снижение массы тела у крыс на 60-е послеоперационные сутки после модифицированной пликации желудка по сравнению с контрольной группой (р <0,01). Однако статистически значимой разницы между массой тела у крыс первой и второй экспериментальной групп на 60-е послеоперационные сутки не обнаружено (p>0,05).

Ключевые слова: пликация желудка; рукавная резекция желудка; морбидное ожирение; сахарный диабет. 